\title{
Transition Into A Green Economy: Are There Limits To Government Intervention?
}

\author{
Edith Kiragu \\ Researcher, Mandela Institute \\ University of Witwatersrand, Johannesburg \\ +27 (0) 11717 8414, Edith.Kiragu@wits.ac.za
}

Sustainable energy has become a priority in many jurisdictions as the impact of climate change is felt across the globe. This has encouraged the deployment of renewable energy by many states in their efforts to transition into green economies. These efforts have been complemented by an increase in the manufacture of renewable energy technologies within the last decade, which has reduced their cost. Trade has played a significant role in facilitating the transfer of renewable energy technologies. Despite the increase in the manufacture of renewable energy technologies, they remain more costly and therefore less competitive with a heavily subsidised and establish fossil fuel industry. The high initial capital cost of renewable energy projects, is the reason why in most jurisdictions, government intervention is key in their deployment. To obtain domestic and political support for renewable energy projects, some governments promise domestic economic development through local content requirements in their national procurement tender programs projects. South Africa is one of these countries. The local content measures enable a government to balance its competing socio-economic priorities and capitalise on the strategic opportunity that a green economy offers in economic development. The challenge that arises is that this kind of government intervention could conflict with international trade law obligations which advocate for, liberalisation of trade by removal of barriers to trade such as tariffs, quotas and measures that amount to protectionism of domestic markets. This paper analyses the local content element in the South African renewable energy procurement tender program, its compatibility with international trade law and the policy space available for government intervention in renewable energy.

Research for this paper was funded by the Swiss State Secretariat for Economic Affairs under the SECO / WTI Academic Cooperation Project, based at the World Trade Institute of the University of Bern, Switzerland.

SECO working papers are preliminary documents posted on the WTI website (www.wti.org) and widely circulated to stimulate discussion and critical comment. These papers have not been formally edited. Citations should refer to a "SECO / WTI Academic Cooperation Project" paper with appropriate reference made to the author(s).

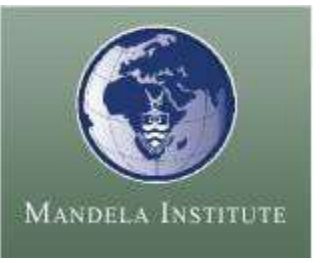




\section{TRANSITION INTO A GREEN ECONOMY: ARE THERE LIMITS TO GOVERNMENT INTERVENTION?}

Edith Kiragu

\section{ABSTRACT}

Sustainable energy has become a priority in many jurisdictions as the impact of climate change is felt across the globe. This has encouraged the deployment of renewable energy by many states in their efforts to transition into green economies. These efforts have been complemented by an increase in the manufacture of renewable energy technologies within the last decade, which has reduced their cost. Trade has played a significant role in facilitating the transfer of renewable energy technologies. Despite the increase in the manufacture of renewable energy technologies, they remain more costly and therefore less competitive with a heavily subsidised and establish fossil fuel industry. The high initial capital cost of renewable energy projects, is the reason why in most jurisdictions, government intervention is key in their deployment. To obtain domestic and political support for renewable energy projects, some governments promise domestic economic development through local content requirements in their national procurement tender programs projects. South Africa is one of these countries. The local content measures enable a government to balance its competing socio-economic priorities and capitalise on the strategic opportunity that a green economy offers in economic development. The challenge that arises is that this kind of government intervention could conflict with international trade law obligations which advocate for, liberalisation of trade by removal of barriers to trade such as tariffs, quotas and measures that amount to protectionism of domestic markets. This paper analyses the local content element in the South African renewable energy procurement tender program, its compatibility with international trade law and the policy space available for government intervention in renewable energy.

Keywords: green economy, local content requirements, procurement tender program, renewable energy, South Africa 


\section{Introduction}

The impact of climate change is felt by all, regardless of whether their country's contribution in Green House Gases (GHG) emissions is significant or not. Sustainable energy has therefore become a priority in many jurisdictions and they have adopted mitigation and adaptation measures to reduce their further contribution to GHG emissions. ${ }^{1}$

South Africa is ranked in the top GHG emitters in the world per GDP standards due to its heavy reliance on coal intensive energy. ${ }^{2}$ Majority of the emissions arise from electricity demand to support the mining and manufacturing industry, the life blood of the economy. ${ }^{3}$ In the UNFCC Copenhagen Climate Change negotiations in 2009, South Africa voluntarily committed to reduce its Green House Gases (GHG) by thirty four percent by 2020 and forty two percent by $2025 .^{4}$

South Africa has limited options in reducing its greenhouse gas emissions unlike other African countries that can adopt policies focused mainly on addressing deforestation to mitigate climate change. ${ }^{5}$ The mitigation options available to South Africa that have a significant contribution to addressing climate change are those focussed on emission reduction. ${ }^{6}$ The best mitigation options to South Africa therefore are energy efficiency, demand management and adoption of low carbon energy sources such as renewable energy. $^{7}$

\footnotetext{
${ }^{1}$ See Richard SJ Tol, 'Long Live the Kyoto Protocol' in Roger Fouquet (ed) Handbook on Energy and Climate Change (Edward Elgar, Cheltenham 2013) 344. Despite the absence of an international climate change agreement, the United Nations Framework Convention on Climate Change (UNFCCC), has been considered to be the major instrument on climate change due to its 'universal ratification. The UNFCCC and its Kyoto protocol have played a central role on climate change in the past decade due to its role in reducing GHG through emission reduction targets set for Annex 1 countries.

${ }^{2}$ Department of Environmental Affairs, 'National Climate Change Response White Paper (October

$2011) 26$.

${ }^{3} \operatorname{Ibid} 26$

${ }^{4}$ Ibid 24-25.

${ }^{5}$ Ibid.

${ }^{6}$ Ibid.

${ }^{7}$ There are other low carbon sources of energy being exploited in South Africa but the focus in this paper will be restricted to renewables. See Integrated Resource Plan for Electricity (IRP) 2010-2030: update report 2013, 34-39. South Africa has currently one nuclear plant (Koeberg) and there are plans to expand generation of nuclear energy There are natural gas reserves in South Africa, in the Karoo basin and there are ongoing plans to start fracking.
} 
The deployment of renewable energy in South Africa has been promoted mostly through domestic policies, laws and regulations. ${ }^{8}$ focus on emission reduction. ${ }^{9}$ South Africa's voluntary pledge to reduce its carbon emission, the climate change policies in place and the energy supply constrains in the country were catalysts for new procurement strategies for renewable energy. ${ }^{10}$ South Africa adopted a Renewable Energy Independent Power Purchasers Procurement Program (REIPPPP) to promote deployment of renewable energy in order to meet its energy demands and international pressures to decarbonise. ${ }^{11}$ This programme however has advanced other policy objectives.

The REIPPPP has a local content requirement which promotes domestic products and local industry development. As most government projects are funded by tax payers, to obtain domestic and political support for renewable energy projects, governments promise domestic economic development due to their other competing socio-economic priorities. ${ }^{12}$ Local content requirements have been argued to contradict with the national treatment principle under World Trade Organisation (WTO) law which dictates equal treatment of domestic and imported products under like circumstances and several cases and complaints have been brought before the WTO. ${ }^{13}$ Despite this being the case, South Africa and many other countries continue to have a local content requirement in their renewable energy procurement programmes or support schemes.

The purpose of this paper is to investigate whether South Africa should reconsider its local content requirement in its renewable energy procurement programme. This paper gives an overview of South Africa's transition into a green economy through the Renewable Energy Independent Power Producers Procurement Programme and the local content requirements within the programme. The second part of the paper reviews the compatibility of the South African renewable energy local

\footnotetext{
${ }^{8}$ Thomas Cottier, 'Renewable Energy and WTO law: More Policy Space or Enhanced Disciplines? (2014) 1 RELP 40.

9 'National Climate Change Response White Paper' (n 2)26

${ }^{10}$ Anton Eberhard and Others, 'South Africa's Renewable Energy IPP Procurement Program: Success Factors and Lessons. (2014) World Bank Report10. Other climate mitigation policies in place include the National Climate Change Response Policy, the National Green Economy Strategy and the National Strategy for Sustainable Development

${ }^{11}$ World Wide Fund (WWF) South Africa, 'Enabling Renewable Energy in South Africa: Assessing the Renewable Energy Independent Power Producer Procurement Program’ (2014) Report Summary 3.

12 JI Lewis, 'the Rise of Renewable Energy Protectionism: Emerging Trade Conflicts and Implications for LOW Carbon Development' Draft for (2014) 14 (4) Global Environmental Politics 3.

${ }^{13}$ Ibid 7-11.
} 
content requirements with international trade law rules. The last section of the paper considers the policy space available for government intervention in promoting renewable energy.

\section{Towards a green economy}

A green economy may be defined to encompass an economy that uses low carbon sources of energy, has adopted resource efficiency mechanisms and ensures social inclusion in this pursuit. ${ }^{14}$ Different interpretations have been given of the term green economy with emphasis being put by some exclusively on reducing the carbon footprint through measures that reduce Green House Gas emissions. ${ }^{15}$ Initiatives taken towards transforming into a green economy may focus mainly on renewable energy, building and energy efficient technology in buildings and infrastructure and the recycling of waste into energy. ${ }^{16}$ Green economy initiatives in this sense fall under the broader climate change mitigation strategies of a country.

The concept of green economy has been used as a tool to advance industrial policies, trade policies and economic development. The foundation of a green economy in South Africa can be said to have been established by the New Growth Path Framework. ${ }^{17}$ New Growth Path was adopted in government in 2010 'as the framework for economic policy and the driver of the country's jobs strategy. ${ }^{18}$ South Africa has underlying social problems of high levels of unemployment enhanced by the global recession and inequality as a consequence of the apartheid regime. ${ }^{19}$ The New Growth Path has an ambitious target of creating five million new jobs by 2020 in the infrastructure, agriculture, mining, tourism and green economy sector, to address inequality and the

\footnotetext{
${ }^{14}$ United Nations Conference on Trade and Development (UNCTAD), 'Local Content Requirements and the Green Economy'(Report) (2014) 19.

${ }^{15}$ WTI Advisors, 'Domestic Requirements and Support Measures in Green Sectors: Economic and Environmental Effectiveness and Implications for Trade: Local Content Requirements and the Green Economy' (2013) 31.

${ }^{16}$ UNCTAD (n 9) 19

${ }^{17}$ Department of Economic Development, Republic of South Africa, The New Growth Path: Framework (23 November 2010).

${ }^{18}$ See http://www.economic.gov.za/communications/51-publications/151-the-new-growth-pathframework accessed 27 November 2015.

${ }^{19}$ New Growth Plan: Framework (n 17)2-6
} 
rising unemployment rates. ${ }^{20}$ The Government's Industrial Policy Plan for 2011-2013 $(\text { IPAP2) })^{21}$ complements the New Growth Plan.

The South African government recognises the opportunity of creating jobs through various partnerships in promoting a green economy and the various processes necessary to create a green economy. ${ }^{22}$ Through the above policies, the South African government has signed number of accords with the public sector and civil society. ${ }^{23}$ The Green Economy Accord ${ }^{24}$ is one of these accords that was developed through social dialogue with various stakeholders and will be mentioned briefly due to its relevance to this topic.

The Green Accord was signed on 17 November $2010^{25}$ just before the 17 th Conference of the Parties (COP 17) to the UN Framework Convention on Climate Change, meeting in Durban in November $2010 .{ }^{26}$ Out of this five million jobs targeted in the New Growth Plan, the Green accord recognises potential of creating 300,000 jobs by 2020 through though activities that promote a green economy. ${ }^{27}$ The targets for the renewable energy sector are 50,000 jobs out of which 6,500 jobs will be allocated to engineers and technicians. $^{28}$

The Accord has 12 commitments towards achieving a green economy. Among these commitments are:

- Increasing investments in the green economy including through the Industrial Development Co-operation(IDC), private investors and retirement funds, 29

- Procurement of renewable energy as part of the energy generation plan, 30

- 'Economic development in the green economy though promotion of localisation, youth employment, cooperatives and skills development. ${ }^{31}$

\footnotetext{
20 Ibid.

${ }^{21}$ Department of Trade and industry, Industrial Policy Plan for 2011-2013 (2010)

${ }^{22}$ Department of Economic Development, New Growth Path: Accord 4, Green Economy Accord (November 2011) 1.(Herein referred to as 'Green Economy Accord')

${ }^{23}$ New Growth Plan: Framework (n 17) 2-6. Other accords include National Skills Accord, Basic

Education Accord, Local Procurement Accord, Youth Employment Accord.

${ }^{24}$ Green Economy Accord (n 22).

${ }^{25}$ Ibid 1.

${ }^{26}$ See http://www.southafrica.info/cop17/green-accord.htm\#.VlfFhlUrLIU (accessed 27 November 2015).

${ }^{27}$ Green Economy Accord (n 22).8.

${ }^{28}$ Ibid 19

${ }^{29}$ Ibid 9

${ }^{30}$ Ibid.
} 


\subsection{Increasing investments in the green economy}

Deployment of renewable is high capital intensive and without financial support mechanism, investment in this sector will not result in desirable returns. The reason for this is that renewables are unable to compete with a well-established fossil fuel energy industry which is heavily subsidized. Global fossil fuel subsidies in 2014 amounted to USD 490 million. $^{32}$ There have been several finance initiatives developed in South Africa to support the green economy. The Accord provides that the IDC will set aside capital for funding projects: R22 billion for green projects and R3 billion for manufacturing of green products and components. ${ }^{33}$ The government through the Department of Environmental Affairs established a Green Fund to be implemented by the Development Bank of South Africa in offering catalytic finance to facilitate green initiatives. $^{34}$

Private investors and donors have also catapulted the green economy. For instance, the 'European Investment Bank and Anglo- African bank Investec of a EUR100 million renewable energy funding facility to promote clean energy and energy efficiency. ${ }^{35}$ The South African Renewables Initiative (SARI) is international partnership initiative which has contributed greatly to developing the renewable energy generation while cushioning the government from incurring huge domestic costs while promoting cleaner energy. ${ }^{36}$ The founding partners of SARI were the governments of South Africa, Denmark, Germany, Norway United Kingdom of Great Britain and Northern Ireland to provide capital to be channelled through a joint initiative by the department of Energy, Trade and Industry and National treasury. ${ }^{37}$

\footnotetext{
31 Ibid.

${ }^{32}$ International Energy Agency: World Energy Outlook 2015 Factsheet: Global energy trends to 2040.available<https://www.iea.org/media/news/2015/press/151110_WEO_Factsheet_GlobalEnergyTren ds.pdf(accessed 27 November 2015).

${ }^{33}$ Green Economy Accord (n 22).9

${ }^{34}$ See <http://www.sagreenfund.org.za/wordpress/>(accessed 27 November 2015) Funding structures of the green fund is through loans, grants and equity

${ }^{35}$ WTI advisors (n 15) 34.

${ }^{36} \mathrm{See}<\mathrm{https}: / /$ sarenewablesinitiative.wordpress.com/>(accessed 27 November 2015)

${ }^{37} \mathrm{See}<$ https://sarenewablesinitiative.wordpress.com/partnership/SARI $>$ (accessed 27 November 2015)

SARI has been developed as part of the South African Industrial Policy Action Plan AND National

Climate Change Response Strategy.
} 


\subsection{Procurement of renewable energy and Localisation}

Although there is an abundance of renewable energy resources in South Africa, for many years' investments were mainly in coal based power generation plants due to the vast coal resources. ${ }^{38}$ The various financial initiatives established within the country have been a great catalyst to investment and the exploitation of this resource. The possible development of the renewable energy sector was first established in the White Paper on the Energy Policy of South Africa ${ }^{39}$ as a medium term policy priority in diversifying the supply of energy in order to ensure energy security. ${ }^{40}$ The South African government paved the way for the adoption of renewable energy in 2003 with the publication of its Renewable Energy Policy White Paper, ${ }^{41}$ which included renewable energy into the country's energy mix by setting targets of generating $10,000 \mathrm{GWh}$ renewable energy by $2013 .^{42}$ No projects however were initiated to meets this targets.

A further boost towards the renewable energy industry was the Integrated Resource Plan (IRP) 2010-2030 ${ }^{43}$ which included in the energy mix of the country 17.8 GW of solar and wind energy capacity by $2030 .{ }^{44}$ South Africa first explored a Renewable Energy Feed in Tariffs (REFIT) programme in 2009, to procure renewable energy from the private sector ${ }^{45}$. Important questions were raised as to the high proposed tariffs, legality and licensing of REFIT before it was implemented. ${ }^{46}$ In March 2011 NERSA called for a review of the REFIT. ${ }^{47}$ The Department of Energy however terminated this program on grounds that it was

\footnotetext{
${ }^{38}$ Department of Minerals and Energy, White Paper on the Renewable Energy of the Republic of South Africa (2003) vii. 'South Africa experiences some of the highest levels of solar radiation in the world' at 20 Herein (White Paper on Renewable Energy)

${ }^{39}$ Ibid.

${ }^{40}$ Ibid 28.

${ }^{41}$ REFIT charges a tariff price about market rates to incentivize investment in the renewable energy sector

${ }^{42}$ White Paper on Renewable Energy (n 38) ix.

${ }^{43}$ Department of Energy, Integrated Energy Resource Plan for Electricity 2010-2030

${ }^{44}$ Ibid.

${ }^{45}$ Anton Eberhard and Others (n 10) 7.

${ }^{46}$ Ibid. See also <http://www.engineeringnews.co.za/article/nersa-moves-to-cut-refit-tariffs-just-as-sapromises-to-boost-renewables-2011-03-22 >(accessed 27 November 2015)

${ }^{47}$ See National Energy Regulator of South Africa(NERSA),NERSA Consulting Paper: Review on Renewable Energy Feed in Tariffs (March 2011) available at <http://www.nersa.org.za/Admin/Document/Editor/file/Electricity/Consultation/Documents/Review\%200 f\%20Renewable $\% 20$ Energy $\% 20$ Feed $\% 2020$ in $\% 20$ Tariff $\% 20$ Consultation $\% 20$ Paper $\% 20$ (Please $\% 20$ note $\%$ 20that \%20table\%20no5\%20on\%20page\%2025\%20has\%20been\%20updated).pdf $>$ (accessed 27 November 2015) See also <http://www.energy.gov.za/files/esources/renewables/REFIT.html >(accessed 27 November 2015)
} 
prohibited under the government's public finance and procurements regulations as it did not promote competitive procurement. ${ }^{48}$

The Department of Energy (DOE) introduced the Renewable Energy Independent Power Producers Programme (REIPPPP) after terminating REFIT. ${ }^{49}$ The REIPPPP was designed as a program that can increase energy generation in a fast and cost effective way while assisting the country to meet its social and environmental objectives. ${ }^{50} \mathrm{~A}$ unique aspect of the programme which has spurred controversial is the strong reliance of economic development requirements in evaluation of bids. ${ }^{51}$ In advancing its socio-economic benefits, a country may use local content requirements. A country's policies can prioritise on advancing technologies that ensure the transition into low carbon economy or put more emphasis on the socioeconomic benefits of creating employment, and developing of infant industry or the promotion of a value adding manufacturing industry. ${ }^{52}$

Simply defined, local content requirements are domestic policies or regulations which require a certain percentage of goods or services to be sourced locally. ${ }^{53}$ Local content requirements can be inferred to 'import quotas on specific goods and services. ${ }^{54}$ Local content requirements may be expressly provided for in regulation and legislation.

When it comes to government procurement, The Preferential Procurement Policy Framework Act(PPFA $)^{55}$ has local content requirements for particular sectors to address the industrial decline in the economy as a result of recession. The PPFA scores bids exceeding R 1 Million 90/10 on price and economic development respectively. ${ }^{56}$ Bids below $\mathrm{R}$ million are scored $80 / 20$ on price and economic development respectively. ${ }^{57}$ The economic development requirements encompassed, local content, job creation,

\footnotetext{
${ }^{48}$ Anton Eberhard (n 10) 10.

${ }^{49}$ Ibid.

${ }^{50}$ World Wide Fund (WWF), Enabling Renewable Energy in South Africa: Assessing the Renewable Energy Independent Power Producer Procurement Program (Report) (2014) 3.

${ }^{51}$ Anton Eberhard and Others (n 10) 11

${ }^{52}$ UNCTAD (n 14) 19.

${ }^{53}$ ) UNCTAD (n 14) 5. See also, Jan-Christoph Kuntze and Tom Moerenhout, 'Local content requirements and the Green Economy- A Good Match?' (2013) (International Centre for Trade and Sustainable Development (ICTSD)) (2014)3. See also, Local Content Requirements and the Renewable Energy Industry 5

${ }^{54}$ UNCTAD (n 14)3.

${ }^{55}$ Act 52000 (revised in 2011.

${ }^{56}$ UNCTAD (n 14) 22

${ }^{57}$ Ibid
} 
ownership, enterprise development and social economic development. ${ }^{58}$ The economic developed aspect in REIPPPP required an exemption by government before the programme was initiated, ${ }^{59}$ as it exceeds the ratio prescribed in the Government Preferential Procurement Policy Act. ${ }^{60}$

The local content requirements can also be de facto. South Africa has a Broad Based Black Economic Empowerment (B-BBEE) Legislation) ${ }^{61}$ enacted in 2003 with a transformation objective to redress inequalities resulting from the apartheid regime. The BBBEE policy framework has a scorecard which assess a contract on ownership, management, employment equity, skills development, preferential procurement and enterprise development of previously disadvantaged South Africans. ${ }^{62}$ Although this local content requirements are not mandatory, they give weighting to a bid presented under REIPPPP.

The first request for proposals (RFP) to procure $3725 \mathrm{MW}$ of renewable energy from the private sector was made by the DOE in August $2011 .^{63}$ The RFP was divided into three sections detailing general requirements, qualification criteria and valuation criteria. The bidders had to provide information relating to the project structure, legal qualifications land, financials and economic development qualifications.

A bid received under the RFP had to undergo evaluation in two processes: the financial evaluation aspect of the project, which accounted for 70 percent of the scoring and the economic development evaluation which accounted for thirty percent of the scoring. ${ }^{64}$ The second bidding period was announced on November 2011 and had more clear local content requirements. The government earmarked certain areas in the manufacturing sector: wind turbine blades and towers, Photovoltaic (PV) modules, PV invertors and metal structures used in PV plants. ${ }^{65}$

\footnotetext{
${ }^{58}$ Ibid13.

${ }^{59}$ WTI Advisors (n 15) 37.

${ }^{60}$ Act no. 5 of 2000 .

${ }^{61}$ No. 53 of 2003., Broad-Based Black Economic Empowerment Amendment Act, 2013 (Act No. 46 of 2013)

62 http://southafrica.smetoolkit.org/sa/en/content/en/7691/Broad-Based-Black-Economic-EmpowermentB-BBEE-explained

${ }^{63}$ World Wide Fund (WWF) (n 50) 1.

${ }^{64}$ Ibid.

${ }^{65}$ Anton Eberhard and Others (n 10) 15-16.
} 
The RFP also indicated that scoring of costs related to the project would be limited to products purchased from South Africa to the exclusion of imported products. ${ }^{66}$

The third RFP announcement in May 2013 included in the local content requirements that 'all raw and unworked steel and aluminium used in the local manufacture of steel would be sourced locally, ${ }^{67}$ and would contribute to the scoring under local content. ${ }^{68}$.The local content requirement was 53.8 percent for Solar PV, 46.9percent wind, 44.3 percent solar CSP and 41 percent landfill gas. ${ }^{69}$ The fourth round of RFP has increased the local content requirements to above sixty four percent for solar PV, 44.6 onshore wind, 40 percent biomass and 40 percent small hydro. ${ }^{70}$ The economic development requirements have been increased in each bidding round as the manufacturing capacity of the country has increased.

There is potential in the local manufacturing of renewable energy technology components. South Africa has vast resources in steel which is used in the manufacture of wind towers, turbines and cooling storage facilities for Concentrated Solar Power production. ${ }^{71}$ The Green accord calls for localisation to ensure that the economy benefits from the greening initiative. ${ }^{72}$ The renewable energy technology sector has already established market players from Europe. ${ }^{73}$ To ensure that foreign investors do not benefit themselves alone through importation of components and skills, localisation is key.

\footnotetext{
${ }^{66}$ Ibid. 16.

${ }^{67}$ Anton Eberhard and Others (n 10) 16.

${ }^{68}$ Ibid 16

${ }^{69}$ See Department of Energy, Renewable Energy IPP Procurement Programme Bid Window 3: Preferred Bidders Announcement available at <http://www.ipprenewables.co.za/\#page/2155> (accessed 15 August 2015).

${ }^{70}$ See Department of Energy, Renewable Energy IPP Procurement Programme, Bid Window 4: Preferred Bidders Announcement (16 April 2015) (Power Point) 25-28 available at http://www.ipprenewables.co.za/\#page/2183 (accessed 15 August 2015). See also <http://www.sapvia.co.za/local-pv-modules-to-play-a-key-role-in-the-reippp-round-4-in-south-africa/> (accessed 15 August 2015).

${ }^{71}$ See_ArcelorMittal South Africa upgrades plate mill to supply rising wind-tower demand http://www.engineeringnews.co.za/article/increased-demand-for-solar-pv-rooftop-solution-expected2014-08-15/searchString:Increased+demand+for+solar+PV+rooftop+solution+expected (accessed 12 September 2014); Natasha Odendaal, MTN unveils first concentrated solar plant<http://www.engineeringnews.co.za/article/mtn-unveils-first-concentrated-solar-plant-2014-07$10>$ (accessed 12 September 2014).

${ }^{72}$ Green Economy Accord (n 22).7. The green accord also commits to support the Integrated Resource Plan 2010-2030 of localisation of 35 percent by 2016and an gradual increase up to 75 percent in the following years. At 19

${ }^{73}$ Jan-Christoph Kuntze and Tom Moerenhout (n 53) 25
} 
Local content requirements in renewable energy are not unique to South Africa. They have been widely used by both developed and developing countries in promoting renewable energy while at the same time advancing certain industrial policies. ${ }^{74}$ Many of the countries have had some form of government intervention in promoting their renewable energy industry through renewable energy feed in tariff programmes or national procurement tender programs.

Brazil for instance subsidises loans offered by its national bank to wind energy projects that meet the criteria of having 60 percent of the total costs locally sourced. ${ }^{75}$ India in its local content requirements requires that all Photovoltaic projects should use locally made cells and modules and thirty percent of solar project costs must be related to local sourcing. ${ }^{76}$ Norway, Malaysia, Nigeria, Ukraine, Turkey, Croatia, Canada, China and the United States of America (USA) are other examples of countries that have had some form of government intervention to promote their renewable energy industry. ${ }^{77}$

\section{$3 \quad$ WTO rules and their interaction with renewable energy policies}

Trade rules also have a role to play in addressing climate change. The preamble of the GATT 1997 for instance advocates for trade that raises the standards of living while allowing for the optimal use of the world's resources which ensures sustainable development and protection of the environment. The interplay between trade policy and the green economy has been contentious in some cases. Trade rules have a positive impact on the green economy where they facilitate the transfer of renewable energy technologies. ${ }^{78}$ In some instances however, trade rules have acted as a stumbling block in the transition into a low carbon economy, as the main objective of trade rules is the liberalization of trade.

The General Agreement on Trade and Tariffs (1995) ${ }^{79}$ and some of its related agreements apply to different aspects related to renewable energy and its technologies. ${ }^{80}$

\footnotetext{
${ }^{74}$ Ibid 21

${ }^{75}$ See, WTI Advisors (n 15)14.

${ }^{76}$ Ibid.

${ }^{77} \mathrm{Id} .13-18$.

${ }^{78}$ Tracey Epps and Andrew Green, Reconciling Trade and Climate: How the WTO Can Help Address Climate Change (Edward Elgar, Cheltenham 2010) 45.

${ }^{79}$ General Agreement on Tariffs and Trade 1994, Apr. 15, 1994, Marrakesh Agreement Establishing the World Trade Organization, Annex 1A 1867 U.N.T.S. 187

${ }^{80}$ See Thomas Cottier (n 8) 42. Other WTO agreements affecting renewable energy: the General Agreement on Trade and Services (GATS), the Agreement on Trade Related Investment Measures (TRIMs), the Agreement on Trade Related Aspects of Intellectual Property Rights (TRIPS), ${ }^{80}$ The
} 
The local content element in many government renewable energy procurement programmes are addressed in GATT Article III, the Agreement on Trade Related Investment Measures (TRIMs) ${ }^{81}$ and the Agreement on Government Procurement (GPA). ${ }^{82}$

The renewable energy industry has had a robust growth within the last decade with China emerging as a major player in large scale manufacturing in the wind and solar energy industry. ${ }^{83}$ China success can be attributed to cheap labour costs, innovation and government support. ${ }^{84}$ The increase in the manufacture of renewable energy technologies within the last decade has increased the supply of renewable energy technologies and reduced their cost. The small-scale manufactures have been affected by this increased competition from China and the various disputes initiated within the WTO dispute settlement mechanism relating to renewable energy can been attributed to these developments. ${ }^{85}$ These cases are linked to subsidies in the renewable energy technology manufacturing or feed in tariffs and local content requirements of government programmes promoting the renewable energy deployment. Most of these cases relate to anti-dumping and countervailing duties. ${ }^{86}$

\subsection{Local Content Requirements and WTO rules}

The most prominent case and the first case under WTO relating to local content requires was the Canada-Measures affecting the Renewable Energy Generating Sector, and Canada-Measures relating to the Feed-In tariff Programme. ${ }^{87} \mathrm{~A}$ complaint had been brought by Japan on Ontario's the feed in tariff programme for wind and solar energy in September 2010 first claiming that the FIT Program discriminated against foreign products and violated the national treatment principle under GATT and also that the program was inconsistent with the TRIMs agreement as it qualified as a prohibited

Agreement on Subsidies and Countervailing Measures (ASCM), the Anti-Dumping Agreement (AD) and the Agreement on Government Procurement (GPA).

${ }^{81}$ Agreement on Trade-Related Investment Measures, Apr. 15, 1994, Marrakesh Agreement Establishing the World Trade Organization, Annex 1A 1868 U.N.T.S. 186.

${ }^{82}$ Agreement on Government Procurement (GPA 1994) Apr. 15, 1994, Marrakesh Agreement

Establishing the World Trade Organization, Annex 4 B. See, Thomas Cottier (n 2)42.

${ }^{83}$ Thomas Cottier (n 8) 42-43.

${ }^{84}$ Id 43.

${ }^{85}$ Id.

${ }^{86}$ Id.

${ }^{87}$ Reports of the Panel(WT/DS412/R; WT/DS426/R, December 19, 2012); Reports of the Appellate Body (WT/DS412/AB/R: WT/DS426/AB/R, May 6, 2013) 
subsidy. ${ }^{88}$ The European Union also initiated a parallel complaint in August 2011 which was heard separately and the panels consolidated their findings. ${ }^{89}$ Canada argued that since it FIT program was a government procurement whose objective was to provide affordable access to clean energy; it was exempt from WTO law. In relation to the complaint, both the panel and the appellate body found that the local content requirement in the Ontario's FIT programme was inconsistent with GATT Article III and the TRIMs Agreement as it required a local content requirement to be met in order to qualify for feed in tariffs. It was also found local content requirement did not qualify as an exemption to national treatment under the TRIMs agreement and Article III (8) (a) GATT as the energy generated was for commercially sale. The appellate body however differed with the panel's interpretation on subsidies and found that Ontario's local content requirement violated Article III: 4 of GATT and Article 2.1 TRIMS Agreement. ${ }^{90}$ Canada was requested to ensure that the Ontario FIT was compliant with WTO. ${ }^{91}$

The violation of the local content requirement under WTO creates a challenge for countries that are signatories to the WTO and have adopted LCR in order to develop their domestic industries. South Africa in particular faces this dilemma as it tries to balance its social economic imperatives with its sustainable energy agendas: by correcting the social inequality resulting from the apartheid era through job creation and enforcing its climate change mitigation objectives, as it is heavily reliant on fossil fuels and in the top GHG emitting global economies in GDP standards. In its REIPPPP, South Africa for instance in bidding window 2 includes $n$ its local requirement criteria local manufacturing of wind turbines blades, PV Modules and inverters and metal structures used in PV plants. ${ }^{92}$ In bidding window 3, the RFP states that locally sourced raw steel and aluminium for local manufacture is calculated as part of meeting the local content requirement criteria.

The local requirement component in the South African REIPPPP gives preference to the purchase of domestic goods over imported products and is in violation of the national treatment principle under GATT Article III. As seen in the Canadian Case on Ontario's FIT, a country's procurement programme is not exempt from the national treatment

\footnotetext{
${ }^{88}$ JI Lewis(n 3) 9

${ }^{89}$ Ibid. The EU and USA joined consultation in September 2010.

${ }^{90}$ Thomas Cottier (n 8) 44.

${ }^{91}$ JI Lewis (n 12) 9.

${ }^{92}$ World Wide Fund (WWF) (n 50)
} 
principle under GATT, where the procurement of energy is for commercial sale. One of the reasons for the design of REIPPPP was to procure fast and cost effective energy to address the current energy crisis. An aggrieved party could therefore initiate a complaint against the South African government procurement programme. The advantage that South Africa has is that the as a result of the decline in the renewable energy industry in OECD, this spurred foreign investment from the international private sector into South Africa's renewable energy sector. ${ }^{93}$. Major players in the renewable energy industry have ownership interest in companies that have been allocated bids to generate renewable energy and are setting up manufacturing plants within the country. South Africa does not have a comparative advantage in this area and so far the complaints that have been initiated before the WTO dispute settlement mechanism relating to local content requirements have been motivated by competition.

In terms of transitioning into a green economy in order to address climate change, local content requirements hinder the transition as they increase the cost of renewable energy technologies. Domestic industry prices may not be as competitive as imports from countries with large scale manufacturing capacity and cheaper labour costs. South Africa has high labour costs as the labour industry is highly unionised and the costs of steel to manufacture some of the component is not as competitive as China. The technology know-how of countries like China has contributed to it becoming a major player and South Africa has a long way to go in terms of innovation. Many components to manufacture the renewable energy technologies would thus have to be imported. These factors are an indication of less competitive pricing from technologies manufactured in countries lacking competitive advantage.

\section{$4 \quad$ Policy space available for government intervention}

Trade has played a significant role in facilitating the transfer of renewable energy technologies. The increase in supply and reduced cost of renewable energy technology components has been attributed to the increased deployment of renewable energy in Europe in the last decade. ${ }^{94}$ There have been efforts to liberalize trade in Environmentally Friendly Goods and services (EGS) and reduce the tariffs on climate friendly goods and services through the Doha Ministerial Declaration 2001. ${ }^{95}$ The

\footnotetext{
${ }^{93} \mathrm{JI}$ Lewis (n 12) 10.

${ }^{94}$ Thomas Cottier (n 8) 44.

${ }^{95}$ Tracey Epps and Andrew Green (n 78) 241-243.
} 
reality of having an Environmental Goods Agreement (EGA) is eminent under the WTO sphere. APEC countries announced in November 2011 that they would develop a list on environment goods which tariffs should be reduced by five percent. ${ }^{96}$ These countries also intend to eliminate non-tariff barriers such as the local content requirement which contributes to trade distortion of climate friendly goods. ${ }^{97}$

The United States and China have agreed on a list of goods during the APEC Summit in 2014. Its success however is questionable as it depends on its support in the Doha Rounds negotiations and currently the debate is not a priority and is overshadowed by the agricultural and industrial market access agenda. ${ }^{98}$ Liberalisation of environmental goods has been perceived to be a mechanism to access the markets by countries leading in the renewable energy manufacturing industry like the United States of America, China, Germany and Spain to promote their interests. ${ }^{99}$ There is policy space for developing countries and least developing countries during to Doha negotiations to be seeking exemptions and justify local content requirements for the protection of their infant industries for a transitional duration. South Africa could lobby under these grounds. Concerns by development in liberalisation of their markets has to be addressed especially because they are not able compete in the environmental goods and services market. $^{100}$

On the contrary, liberalisation of environment goods could work in South Africa's advantage in the future. There is a lot of potential in renewable energy in Africa due to its vast natural resources and the fact that most of its population remain unelectrified. ${ }^{101}$ The development of manufacture of renewable energy technology in South Africa creates a potential market for it within the continent as renewable remains under exploited due to the high initial costs. South Africa is a leading exporter of various goods within the SADC region and the rest of the continent.

\footnotetext{
96 Ibid.

${ }^{97}$ Ibid.

${ }^{98}$ Peet du Plooy \& Meagan Jooste, 'Trade and Climate Change: Policy and Economic implications for South Africa (Paper submitted for the Mitigation Action Plans \& Scenarios project) (2011) 5. See also Veena Jha, 'Environmental Goods: a Reality Check' in UNCTAD, Trade and Environment Review: Promoting Poles of clean growth to foster the transition to a more sustainable economy (New York 20092010) 199.

${ }^{99}$ Ibid 5.

${ }^{100}$ ZhongXiang Zhang, 'Liberalizing Climate friendly Goods and Technologies in the WTO: Product Coverage, Modalities, Challenges and the Way Forward' in UNCTAD, (n 46) 179.

${ }^{101}$ See http://www.bdlive.co.za/opinion/2015/09/21/renewable-energy-is-sas-solution(accessed 27 November 2015)
} 
Local content requirements however can be accorded some policy WTO law. ${ }^{102}$ The renewable energy industry has a service element as it reliant on certain skills in the deployment and maintenance of the technologies. GATS allows for domestic policies to be developed to support the development of the service providers and the industry. ${ }^{103}$

For local content requirement not to act as an impediment to attracting foreign investment, most governments package them together with other investment incentives. The reasoning behind this is that in most cases where local content requirements are adopted, domestic inputs are less efficient than imported inputs and this increases production costs and ultimately the cost price of a unit. ${ }^{104}$ In addition to or in the alternative, investors are required to meet certain performance requirements such as employment, technology transfer, research and development, domestic ownership in order to enjoy the investment incentive. ${ }^{105}$ Investment incentives vary from country to country, they may relate to financial assistance, tax credits, bonus payments or eligibility to qualify for a procurement process. ${ }^{106}$

\section{Conclusion}

The local content requirement has been adopted by many countries to transition into low carbon economies. Although it has been argued that domestic industry prices may not be as competitive as imports from countries with large scale manufacturing capacity and cheaper labour costs, the evidence of the significant contribution by government intervention in the renewable energy industry has started changing the perceptions towards local content requirements. Some countries have even linked investment into the green economy as a result of local content requirements. South Africa is one of these countries.

There is a possibility of having an Environmental Goods Agreement liberalizing trade in environmental goods and services however these might be achieved in the near future as countries continue deliberating on agricultural and industrial market access agenda in the Doha Round negotiations. Although the local content requirement in the South

\footnotetext{
${ }^{102}$ Thomas Cottier (n 8) 45

${ }^{103}$ Ibid.

${ }^{104}$ UNCTAD (n 14) 12.

${ }^{105}$ Ibid 3.

${ }^{106}$ Jan-Christoph Kuntze and Tom Moerenhout (n 38) 5.
} 
African REIPPPP may be considered to violate its WTO obligations, there is lobbying space within the negotiations of the EGA where South Africa can seek exemptions and justify its local content requirements for the protection of its infant industries. The benefits accrued by a well-structured local content requirement in promoting value addition domestically and international competitiveness of that jurisdiction in the renewable energy industry can justify temporary incompatibility of local content requirements.

On the service aspect in the deployment of renewable energy, the local content requirement in the South Africa REIPPPP can be justified under GATS. It can be said however that local content requirements are emerging again in trade and industrial policies despite the cases initiated at the WTO. This may create more policy space within international trade law in order to facilitate the transition into a global green economy. 


\section{References}

Richard SJ Tol, 'Long Live the Kyoto Protocol' in Roger Fouquet (ed) Handbook on Energy and Climate Change (Edward Elgar, Cheltenham 2013)

Thomas Cottier, 'Renewable Energy and WTO law: More Policy Space or Enhanced Disciplines? (2014) 1 RELP

JI Lewis, 'The Rise of Renewable Energy Protectionism: Emerging Trade Conflicts and Implications for LOW Carbon Development' Draft for (2014) 14 (4) Global Environmental Politics

Tracey Epps and Andrew Green, Reconciling Trade and Climate: How the WTO Can Help Address Climate Change (Edward Elgar, Cheltenham 2010)

World Wide Fund (WWF) South Africa, 'Enabling Renewable Energy in South Africa: Assessing the Renewable Energy Independent Power Producer Procurement Program' (2014) Report Summary 3.

Department of Minerals and Energy, White Paper on Renewable Energy (November 2013)

Department of Environmental Affairs, 'National Climate Change Response White Paper (October 2011)

Preferential Procurement Policy Act Act no. 5 of 2000

WTI Advisors, 'Domestic Requirements and Support Measures in Green Sectors: Economic and Environmental Effectiveness and Implications for Trade' (2013) Expert Group Meeting Report

General Agreement on Tariffs and Trade 1994, Apr. 15, 1994, Marrakesh Agreement Establishing the World Trade Organization, Annex 1A 1867 U.N.T.S. 187

Agreement on Trade-Related Investment Measures, Apr. 15, 1994, Marrakesh Agreement Establishing the World Trade Organization, Annex 1A 1868 U.N.T.S. 186 
Peet du Plooy \& Meagan Jooste, 'Trade and Climate Change: Policy and Economic implications for South Africa(Paper submitted for the Mitigation Action Plans \& Scenarios project (2011),

Veena Jha, 'Environmental Goods: a Reality Check' in UNCTAD, Trade and Environment Review: Promoting Poles of clean growth to foster the transition to a more sustainable economy (New York 2009-2010)

ZhongXiang Zhang, 'Liberalizing Climate friendly Goods and Technologies in the WTO: Product Coverage, Modalities, Challenges and the Way Forward' in UNCTAD Trade and Environment Review: Promoting Poles of clean growth to foster the transition to a more sustainable economy (New York 2009-2010) 